\title{
Muscle Size and Strength Benefits of Functional Electrical Stimulation-Evoked Cycling Dosage in Spinal Cord Injury: A Narrative Review (Faedah Dos Rangsangan-Elektrik Berfungsi Berbasikal terhadap Saiz dan Kekuatan Otot pada Kecederaan Saraf Tunjang: Suatu Kajian Naratif)
}

\author{
Nurhaida Rosley, Nur AZAH HamZaid, NAZIRAH HASNAN, GLEN M DAVIS \& HAIDZIR MANAF*
}

\begin{abstract}
Loss of sensory motor function is one of the main causes of physical and activity limitations among individual with spinal cord injury (SCI). SCI may lead to muscle paralysis, weakness and disused muscle atrophy. Evidences have shown electrical stimulation and strengthening exercise might improve lower limb muscle strength and size among individual with SCI. Functional electrical stimulation (FES) evoked cycling is one of the methods that can elicit leg muscle contractions in order to produce a cycling motion and promote the integrity of the involved muscles. Therefore, this review is to synthesize the scientific literature regarding the effects of multiple dosages of FES-evoked lower limb cycling on muscle properties. A systematic literature search from 1946 to 2016 was performed. From over 1,139 articles retrieved from the database, about 31 potentially relevant articles were retained for possible inclusion. However, only 10 articles out of 31 articles fulfilled the inclusion criteria. Although the available evidence is compelling, there is insufficient quantity and quality evidence to draw conclusions regarding the specific parameter of FES-CE that may optimally increase muscle strength, mass, and circumference. However, it can be safely concluded that an effective training session would spend for 45-60 min, 3 times a week for at least 4 weeks to see changes in muscle size and strength.
\end{abstract}

Keywords: Cycling exercise; functional electrical stimulation; muscle strength; spinal cord injury

\section{ABSTRAK}

Kehilangan fungsi deria motor adalah salah satu punca kepada pembatasan fizikal dan aktiviti dalam kalangan individu yang mengalami kecederaan saraf tunjang. Kecederaan saraf tujang boleh mengakibatkan kelumpuhan otot, kelemahan dan ketidakgunaan otot atau atrofi. Bukti menunjukkan stimulasi elektrik dan senaman kekuatan otot boleh memperbaiki saiz dan kekuatan otot bahagian kaki dalam kalangan individu yang mengalami kecederaan saraf tunjang. Sistem berbasikal rangsangan FES adalah salah satu metod yang boleh merangsang kontraksi otot kaki untuk menghasilkan pergerakan berbasikal dan meningkatkan integriti otot yang terlibat. Oleh itu, kajian ini adalah bertujuan untuk mensintesis kepustakaan saintifik untuk mengkaji kesan pelbagai dos rangsangan FES untuk anggota bawah berbasikal pada sifat otot. Satu carian kepustakaan secara sistematik telah dijalankan dari 1946 hingga 2016. Daripada 1,139 artikel yang didapati daripada pangkalan data, 31 artikel yang berpotensi telah dikekalkan mengikut kebarangkalian inklusi. Walau bagaimanapun, hanya 10 artikel daripada 31 artikel memenuhi kriteria rangkuman. Walaupun bukti yang didapati sangat menarik perhatian, namun kuantiti dan kualitinya tidak mencukupi untuk dijadikan kesimpulan berkaitan dengan parameter khusus FES-CE yang mampu meningkatkan kekuatan, jisim dan ukur lilit otot secara optimum. Namun, ia selamat untuk disimpulkan bahawa keberkesanan suatu sesi latihan mengambil masa 45-60 minit, 3 kali seminggu untuk sekurang-kurangnya 4 minggu untuk melihat perubahan saiz dan kekuatan otot.

Kata kunci: Kecederaan saraf tunjang; kekuatan otot; rangsangan elektrik berfungsi; senaman berbasikal

\section{INTRODUCTION}

Spinal cord injury (SCI) is one of the leading causes of physical disability worldwide. In the USA, approximately 17,000 new cases of SCI were reported each year due to road traffic accident, falls, and sports (National Spinal Cord Injury Database 2015). It can be pronounced that the consequences after SCI is usually a profound reduction in the muscle mass, strength, and muscle volume (Dionyssiotis et al. 2015). Thus, as a result of this muscle integrity degeneration, it could lead to lower limb muscle weakness and muscle atrophy. These can affect their quality of life in which long-term recovery and rehabilitation process is required (LiVecchi 2011; Westcott \& Rosa 2010).

It has been widely established that exercise and training programs for individual with SCI could enhance their muscle power function and prevent muscle atrophy (American College of Sports Medicine 2010). Thus, a suitable exercise regime can help in achieving these goals and reduce the risk of secondary health problems accompanying with physical inactivity. One of the technique is by applying the functional electrical stimulation (FES). This device will assist exercise through the application of a low-level 
electrical stimulation current on muscle motor control to evoke muscle contraction (Lynch et al. 2008; Peckham \& Knutson 2005). There have been so many method with FES, however, FES evoked cycling exercise (FES-CE) has been widely used in clinical settings for aerobic and strength training applications (Estigoni et al. 2011; Fornusek et al. 2013; Kuhn et al. 2014; Thrasher et al. 2013). Technically, FES-CE is a computer-controlled electrical stimulation that elicits leg muscle contractions in order to produce a cycling motion and promote the integrity of the involved muscles (Ragnarsson 2008). Based on a study by Hamzaid and Davis (2009), the FES-CE could increase muscle size and volume, and prevent the alteration of muscle morphology in individuals with lower motor neuron lesions SCI (Hamzaid \& Davis 2009). Therefore, the ultimate goal of this intervention is to provide therapeutic gains for persons with SCI (Estigoni et al. 2011; Fornusek \& Davis 2004; Hasnan et al. 2013)

Despite numerous studies of FES-CE effect on muscle size and muscle strength among individual with SCI, no evidence concerning about its appropriate dosage of training. In this narrative review, inclusive review of obtainable literature was provided to verify the effects of FES-CE on muscle size and muscle strengths among individual with SCI. By providing the quality of evidence and dosage for this kind of training, it may help the medical practitioners to decide on its proper application. Thus, the aim of this review was to synthesize the scientific literature to explore the multiple dosages of FES-CE that is adequate to improve muscle properties and characteristics including muscle mass, volume, and strength for individuals with SCI.

\section{METHODS: StUdy SELECTION}

A systematic literature search was conducted by using electronic databases: ProQuest, Science Direct, MEDLINE between 1946 and October 2016; Ovid MEDLINE Daily Update; and Web of Science between 1980 and 2016. For a wider coverage, the literature searches also included manual searches of clinical rehabilitation specific journals including Clinical Rehabilitation, Spinal Cord, Physiotherapy, Physical therapy and multidisciplinary journals for examples, BMJ, Lancet, and JAMA. The search strategy for reviews on our topic was also carried out using the Cochrane Library and Cochrane Database for Systematic Reviews. The literature search was, however, limited to human research studies, based on any language if the translation of English abstract provides a clear description of the study and the outcome measures. All systematic literature findings were explored by the author based on certain inclusion criteria until it reaches 'saturation point.'

The inclusion criteria for this review was that the studies must involve the following: functional electrical stimulation (FES); or functional neuromuscular stimulation (FNS) evoked cycling; lower limbs cycling; outcome should be measured on the effects of the cycling exercise on improvement or otherwise of muscle strength, mass, and volume; and in persons with spinal cord injury. In addition, studies that involved a combination of FESevoked upper limb and lower limb exercise were included, if they provide lower limbs muscle strength as one of the outcome measures. Keywords used in this review were: FES, FNS, functional electrical stimulation, functional neuromuscular stimulation, electrical stimulation, functional stimulation, neuromuscular stimulation, neurostimulation; training, exercise, cycling; SCI, spinal cord survivors, paraplegic, paraplegia, quadriplegic, tetraplegia, tetraplegic, paralyzed, paralysis; subjects, participants, patients, human, persons; muscle strength, muscle atrophy, muscle mass, muscle volume, muscle circumference and muscle properties. The title of all the potentially eligible studies were scanned manually using Google Scholar search engine. On the first round of search, 1,139 experimental studies were discovered. Thus, the second round of search included randomized controlled trial (RCT), quasi-experimental research (randomized only or controlled only), case-controlled study, observation studies and crossover designs. As highlighted earlier only studies that recruited persons with SCI for the experiment and control group were retained. Studies that recruited able-bodied participants as the control were excluded. This was due to the knowledge that the inference or conclusion from such studies may not be sufficient to verify the proposed hypothesis (Hamzaid \& Davis 2009). In the present review, the RCT and quasi-RCT retained were meant to provide a strong evidence whereas the other studies were used as supporting evidence for the hypothesis of the study.

\section{RESULTS}

The articles from RCT, quasi-RCT, nonrandomized or controlled studies and cross-sectional or crossover designs were retained for this review as they provide the scientific evidence regarding the FES-CE. The article search was conducted from February 2016 until October 2016. From over 1,139 articles retrieved from the database, about 31 potentially relevant articles were retained for possible inclusion. However, only 10 articles out of 31 articles fulfilled the inclusion criteria. All the 10 studies reported muscle size and strength benefits effect following FES-CE in individuals with SCI (Table 1). All studies had samples sizes ranging from 8-45 participants.

Muscle size has generally been measured as body lean mass by using bioelectrical impedance analysis and Lunar DPX X-ray to determine lesser fat or bigger muscle after FES-CE training (Baldi et al. 1998; Liu et al. 2007). Muscle circumference usually measured in the supine position using a tape measure (Fornusek et al. 2013; Kuhn et al. 2014; Liu et al. 2007). The measurements were usually reported before and after the FES-CE training based on the anatomical landmarks chosen by researchers. Significant improvement of muscle peak torque has been reported in individuals with SCI after FES-CE training 
TABLE 1. Studies reported muscle size and strength benefits effect following FES-evoked lower limb cycling exercise in individuals with SCI

\begin{tabular}{|c|c|c|c|c|}
\hline References & Sample & Duration & Intervention & Main result \\
\hline $\begin{array}{l}\text { Johnston et al. } \\
\text { (2015) }\end{array}$ & $\begin{array}{l}\mathrm{N}=17 \\
\text { Complete SCI }\end{array}$ & 6 months & $\begin{array}{l}\text { FES cycling } \\
1 \text {-hour } \times 3 \text { times per week } \\
\text { Low cadence vs. high cadence }\end{array}$ & $\begin{array}{l}\text { Muscle volume } \\
\text { Low cadence group increased by } 19 \% \text {, high cadence group } \\
\text { increase by } 10 \%\end{array}$ \\
\hline Sköld et al. (2002) & $\begin{array}{l}\mathrm{N}=15 \\
\text { Complete SCI }\end{array}$ & 6 months & $\begin{array}{l}\text { FES cycling } \\
30 \mathrm{~min} \times 3 \text { times per week } \\
\text { Freq }=30 \mathrm{~Hz} \mathrm{PW}=350 \mu \mathrm{sec} \\
\text { Stim }=\text { up to } 130 \mathrm{~mA} \\
\text { Pedal cadence }=35 \mathrm{rpm}\end{array}$ & $\begin{array}{l}\text { Muscle volume } \\
\text { Group trained with FES increased } 1300 \mathrm{~cm}^{3}(p<0.001) \text { than } \\
\text { those in the control group }\end{array}$ \\
\hline Kuhn et al. (2014) & $\begin{array}{l}\mathrm{N}=30 \\
\text { Complete SCI } \\
\text { vs. Incomplete } \\
\text { SCI }\end{array}$ & 4 weeks & $\begin{array}{l}\text { FES-CE } \\
20 \mathrm{~min} \times 2 \text { times per week } \\
\text { Freq }=30 \mathrm{~Hz} \mathrm{PW}=250 \mu \mathrm{sec} \\
\text { Stim }=10-130 \mathrm{~mA} \\
\text { Pedal cadence }=15-55 \mathrm{rpm}\end{array}$ & $\begin{array}{l}\text { Circumferences } \\
\text { Greater improvement in incomplete group }(p<0.05) \\
\text { Manual muscle testing } \\
\text { Those in incomplete group reported } 43.5 \% \text { increase }(p<0.001) \\
\text { in quadriceps femoris muscle and } 25 \%(p<0.001) \text { in gluteus } \\
\text { maximus muscle }\end{array}$ \\
\hline $\begin{array}{l}\text { Thrasher et al. } \\
\text { (2013) }\end{array}$ & $\begin{array}{l}\mathrm{N}=11 \\
\text { Complete SCI } \\
\text { vs. incomplete } \\
\text { SCI }\end{array}$ & 13 weeks & $\begin{array}{l}\text { FES-LCE training } \\
1 \mathrm{~h} \times 3 \text { times per week, } \\
40 \mathrm{sessions} \\
\text { Freq }=30 \mathrm{~Hz} \mathrm{PW}=250 \mu \mathrm{sec} \\
\text { Stim }=\text { up to } 140 \mathrm{~mA} \\
\text { Pedal cadence }=45 \mathrm{rpm}\end{array}$ & $\begin{array}{l}\text { Peak torque } \\
\text { Both groups had improved knee extension torque } 3.8 \text { to } 16.9 \mathrm{Nm} \\
(p=0.006) . \text { However, those in incomplete group shown greater } \\
\text { improvement }\end{array}$ \\
\hline $\begin{array}{l}\text { Fornusek et al. } \\
\text { (2013) }\end{array}$ & $\begin{array}{l}\mathrm{N}=8 \\
\text { Complete and } \\
\text { Incomplete SCI }\end{array}$ & 6 weeks & $\begin{array}{l}\text { FES-CE } \\
30 \text { min } \times 3 \text { times per week } \\
1 \text { leg on low cadence } 10 \mathrm{rpm} \\
\text { and the other leg on high } \\
\text { cadence } 50 \mathrm{rpm} \\
\text { Freq }=35 \mathrm{~Hz} \mathrm{PW}=250 \mu \mathrm{sec} \\
\text { Stim }=40-140 \mathrm{~mA}\end{array}$ & $\begin{array}{l}\text { Thigh girth } \\
\text { Both groups reported greater improvement on low cadence } \\
\text { Quadriceps peak torque } \\
\text { Quadriceps peak torque has increased } 87 \% \text { in low cadence }\end{array}$ \\
\hline $\begin{array}{l}\text { Sadowsky et al. } \\
\text { (2013) }\end{array}$ & $\begin{array}{l}\mathrm{N}=45 \\
\text { Complete and } \\
\text { Incomplete SCI }\end{array}$ & 29.1 month & $\begin{array}{l}\text { FES-CE } \\
50-60 \mathrm{~min} \times 3 \text { times per week } \\
\text { Freq }=100 \mathrm{~Hz} \mathrm{PW}=500 \mu \mathrm{sec} \\
\text { Stim }=\text { up to } 140 \mathrm{~mA} \\
\text { Pedal cadence }=50 \mathrm{rpm}\end{array}$ & $\begin{array}{l}\text { Muscle volume } \\
\text { Those in FES group had significantly higher anterior ( } 36 \% ; 96.3 \\
\text { cc; } p \leq 0.001 \text { ) and posterior }(30 \% ; 63.9 \mathrm{cc} ; p=0.005) \text { thigh } \\
\text { compartment muscles than those in the control group } \\
\text { Muscle strength } \\
\text { trained muscles of the FES group was significantly greater } \\
\text { (quadriceps, } p=0.006 \text {; hamstrings, } p=0.011 \text { ) than in controls }\end{array}$ \\
\hline $\begin{array}{l}\text { Duffell et al. } \\
\text { (2008) }\end{array}$ & $\begin{array}{l}\mathrm{N}=11 \\
\text { Complete SCI }\end{array}$ & 1 year & $\begin{array}{l}\text { FES cycling } \\
1 \mathrm{~h} \times 5 \text { times } / \text { week } \\
\text { Freq }=50 \mathrm{~Hz} \text { if rapid fatigue } 10 \\
\text { Pedal cadence }=45-55 \mathrm{rpm}\end{array}$ & $\begin{array}{l}\text { Quadriceps Maximal Torque } \\
\text { Increased progressively and significantly throughout training } \\
(p=0.012) \text {. It had increased by } 399 \% \text { and } 673 \% \text { after } 3 \text { and } 12 \\
\text { months }\end{array}$ \\
\hline Liu et al. (2007) & $\begin{array}{l}\mathrm{N}=18 \\
\text { Complete and } \\
\text { Incomplete } \\
\text { SCI }\end{array}$ & 8 weeks & $\begin{array}{l}\text { FES-CE } \\
30 \mathrm{~min} \times 3 \text { times per week } \\
\text { Freq }=30 \mathrm{~Hz} \mathrm{PW}=300 \mu \mathrm{sec} \\
\text { Stim }=10-130 \mathrm{~mA} \\
\text { Pedal cadence }=45 \mathrm{rpm}\end{array}$ & $\begin{array}{l}\text { Body lean mass } \\
\text { Mild increase after } 8 \text { weeks training }(p=0.03) \\
\text { Limb girth } \\
\text { Significant increase in both upper and lower limb girth after } 4 \\
\text { and } 8 \text { weeks of training }(p<0.05) \\
\text { Peak torque } \\
\text { Shown improvement only after } 8 \text { weeks training }(p<0.05)\end{array}$ \\
\hline $\begin{array}{l}\text { Demchak et al. } \\
\text { (2005) }\end{array}$ & $\begin{array}{l}\mathrm{N}=10 \\
\text { Complete SCI }\end{array}$ & 13 weeks & $\begin{array}{l}\text { FES-CE } \\
30 \mathrm{~min} 33 \mathrm{x} \text { per week } \\
\text { Freq }=35 \mathrm{~Hz} \\
\text { Pedal cadence }=35 \mathrm{rpm}\end{array}$ & $\begin{array}{l}\text { Cross-sectional area (muscle biopsy) } \\
\text { Group trained with FES-CE increased CSAf } 171 \% \text { greater than } \\
\text { the CSAf in the control group }(p=0.05)\end{array}$ \\
\hline Baldi et al. (1998) & $\begin{array}{l}\mathrm{N}=26 \\
\text { Complete SCI }\end{array}$ & $\begin{array}{c}3 \text { month }+6 \\
\text { month }\end{array}$ & $\begin{array}{l}\text { FES-CE } \\
30 \mathrm{~min} \times 3 \text { times per week, } \\
\text { FES-IC } \\
1 \mathrm{~h} \times 5 \text { times per week } \\
\text { Freq }=60 \mathrm{~Hz} \mathrm{PW}=375 \mu \mathrm{sec} \\
\text { Stim }=\text { up to } 140 \mathrm{~mA} \\
\text { Pedal cadence }=35-50 \mathrm{rpm}\end{array}$ & $\begin{array}{l}\text { Lean body mass } \\
\text { FES-CE showed a significant hypertrophy after } 6 \text { months on } \\
\text { both lower limb and gluteal lean body mass in comparison to } \\
\text { FES alone }\end{array}$ \\
\hline
\end{tabular}

FES-CE = Functional Electrical Stimulation-Cycling Ergometer; FES-LCE = Functional electrical Stimulation Leg Cycling Ergometer; FES-IC $=$ Functional Electrical Stimulation Isometric Contraction, N= Number of participants, Freq= Frequency, PW= Pulse Width, Stim= Stimulation 
(Duffell et al. 2008; Fornusek et al. 2013; Liu et al. 2007; Sadowsky et al. 2013; Thrasher et al. 2006). However, individuals with incomplete SCI has been found to have a greater improvement than those with complete SCI (Fornusek et al. 2013; Sadowsky et al. 2013; Thrasher et al. 2013). Therefore, available evidence showed that the strength gains during FES-CE training were positively related to the spared muscle function after SCI trauma. This may suggest that SCI individuals with higher residual muscle strength might achieve better results from the cycling training.

\section{DISCUSSION}

This review yielded only 10 articles that emphasize the effect of FES-evoked cycling exercise on muscle size and muscle strength among individual with SCI. It has been proven that this type of exercise is highly relevant modality for individual with chronic SCI as it has a significant impact on their capability to perform activities of daily living. Additionally, it has been identified that the FES-CE does not only improve muscle size, it also promotes the quality of life of incomplete SCI individuals in particular.

\section{EFFECTS OF FES-CE ON MUSCLE SIZE}

Individuals who were trained with FES-CE had shown significant improvement in muscle mass and muscle girth after 4 weeks (Kuhn et al. 2014). However, it has been identified that the training should start within the first 3 months after a SCI to ensure the efficacy of FES-CE training (Baldi et al. 1998). Baldi et al. (1998) have shown that FESCE could prevent the progression of muscle mass reduction after 6 months of training. Paralysis and episode of sedentary lifestyle after chronic SCI could lead to elevation of fat mass and reduction of lean body mass percentage (Giangregorio et al. 2005). Notably, individuals with acute SCI only have $60-65 \%$ lean mass than their able-bodied counterparts and their fat gain can be up to $100-113 \%$ of their able-bodied counterparts (Giangregorio et al. 2005). Therefore, this may lead to a serious long-term health complication that may compromise with their quality of life (Hicks et al. 2011).

Nevertheless, the significant changes in leg lean mass following FES-CE training for incomplete SCI has been reported to be greater than in complete SCI individuals even in a short-term ( 8 weeks) cycling training (Liu et al. 2007). Hypertrophy of stimulated muscle has also been observed after both short and long-duration FES-CE protocol (Fornusek et al. 2013; Kuhn et al. 2014). Additionally, although a non-significant general increase of body lean mass in completely paralyzed individuals has been reported, such increase has a positive effect in preventing muscle atrophy of stimulated muscles (Baldi et al. 1998). Based on the literature reviewed, we can safely infer that FES cycling with 3 days per week training for more than 4 weeks could prevent the loss of muscle mass (Fornusek et al. 2013; Kuhn et al. 2014).

\section{EFFECTS OF FES-CE ON MUSCLE STRENGTH}

Evidence suggested that in order to achieve greater dramatic effects of muscle strength, the stimulation parameters used in the FES-CE training must be able to increase fatigue-resistance of muscles (Fornusek et al. 2013; Johnston et al. 2015). Low-cadence (10 rpm) but not high-cadence (i.e. $50 \mathrm{rpm}$ ) cycling has been shown to promote increased fatigue-resistance of the quadriceps muscle (Fornusek et al. 2013). This result was supported by earlier recommendation that the health effects from FES-CE should be maximized for SCI survivors (Duffell et al. 2008; Liu et al. 2007). As evident from the reviewed literature, most FES-CE cycle ergometers are designed to operate at a cadence of $50 \mathrm{rpm}$. However, fatigue develops more slowly during FES-CE at lower pedal cadences, allowing greater muscle forces to be maintained (Johnston et al. 2015). Therefore, continuous stimulation in muscle's normal physiological frequency range $(30-35 \mathrm{~Hz}$ ) (Demchak et al. 2005; Duffell et al. 2008; Sadowsky et al. 2013) and pulse width (250-300 $\mu \mathrm{sec})$ (Baldi et al. 1998; Johnston et al. 2015; Liu et al. 2007) may offer a better electrical stimulus effect that could promote adaptation of a muscle to be more fatigue resistant. In a total of 10 studies, not all studies stated the resistance used while cycling with FES. However, it seemed that by increasing the resistance every $\sim 3 \mathrm{~W}-\sim 6 \mathrm{~W}$ if participants able to maintain rotation per minutes of the cadence by three consecutive $30 \mathrm{~min}$ training sessions it could give more impact to the strength of the muscle (Demchak et al. 2005; Liu et al. 2007; Thrasher et al. 2013).

\section{CONCLUSION}

Although the available evidence is compelling, there is insufficient quantity and quality evidence to draw conclusions regarding the specific parameter of FES-CE that may optimally increase muscle strength, mass, and circumference. Nevertheless, based on Table 1, it can be safely concluded that an effective training session would spend between 45 and $60 \mathrm{~min}, 3$ times a week for at least 4 weeks to see changes in muscle size and strength. The FES stimulation parameters of 250-300 microseconds pulse width, current amplitude $40 \mathrm{~mA}-140 \mathrm{~mA}, 30-35 \mathrm{~Hz}$ frequency are optimally administered for each participant. Studies on leg FES-cycling have only been carried out in persons with complete SCI or those with a combination of complete and incomplete SCI. However, a lesser attention has been paid to the effects of FES-cycling on persons with incomplete SCI. Although FES-cycling in persons with incomplete SCI may give a greater improvement in muscle strength, the affected population may not be able to tolerate electrical stimulation of a similar intensity as administered to complete SCI survivors. Thus, further quality research is needed to examine the most suitable parameters that can be used to maximize its effectiveness. For clinical rehabilitation applications, a standardized FES-evoked cycling protocol will be guiding especially for clinicians 
and other allied health professional administering FEScycling for strength training.

\section{ACKNOWLEDGEMENTS}

The authors would like to thank Dr Morufu Olusola Ibitoye, for assisting with the preparation of the manuscript. We also would like to thank Universiti Malaya for the High Impact Research (HIR) Grant (Ref No: UM.C/HIR/MOHE/ ENG/39) and Fundamental Research Grant Scheme (FRGS) awarded by the Ministry of Higher Education, Malaysia (Ref No: 600-RMI/FRGS 5/3 (0008/2016)) for funding the manuscript process.

\section{REFERENCES}

American College of Sports Medicine (ACSM). 2010. ACSM's Resources for Clinical Exercise Physiology: Musculoskeletal, Neuromuscular, Neoplastic, Immunologic and Hematologic Conditions (ACSMs Resources for the Clinical Exercise Physiology).2nd edition. Philadelphia: Lippincott, Williams and Wilkins.

Baldi, J.C., Jackson, R.D., Moraille, R. \& Mysiw, W.J. 1998. Muscle atrophy is prevented in patients with acute spinal cord injury using functional electrical stimulation. Spinal Cord 36: 463-469.

Demchak, T.J., Linderman, J.K., Mysiw, W.J., Jackson, R., Suun, J. \& Devor, S.T. 2005. Effects of functional electric stimulation cycle ergometry training on lower limb musculature in acute SCI individuals. Journal of Sports Science and Medicine 4(3): 263-271.

Dionyssiotis, Y., Stathopoulos, K., Trovas, G., Papaioannou, N., Skarantavos, G. \& Papagelopoulos, P. 2015. Impact on bone and muscle area after spinal cord injury. BoneKEy Reports 4(1): $1-8$.

Duffell, L.D., Donaldson, N.D.N., Perkins, T.I.M.A. \& Ms, C. 2008. Long-term intensive electrically stimulated cycling by spinal cord-injured people: Effect on muscle properties and their relation to power output. Muscle Nerve 38(4): 1304-1311.

Estigoni, E.H., Fornusek, C., Smith, R.M. \& Davis, G.M. 2011. Evoked EMG and muscle fatigue during isokinetic FEScycling in individuals with SCI. Neuromodulation: Journal of the International Neuromodulation Society 14(4): 349-355.

Fornusek, C. \& Davis, G. 2004. Maximizing muscle force via low-cadence functional electrical stimulation cycling. Journal of Rehabilitation Medicine 36(5): 232-237.

Fornusek, C., Davis, G.M. \& Russold, M.F. 2013. Pilot study of the effect of low-cadence functional electrical stimulation cycling after spinal cord injury on thigh girth and strength. Archives of Physical Medicine and Rehabilitation 94(5): 990-993.

Giangregorio, L.M., Hicks, A.L., Webber, C.E., Phillips, S.M., Craven, B.C., Bugaresti, J.M. \& McCartney, N. 2005. Body weight supported treadmill training in acute spinal cord injury: Impact on muscle and bone. Spinal Cord: The Official Journal of the International Medical Society of Paraplegia 43(11): 649-657.

Hamzaid, N.A. \& Davis, G.M. 2009. Health and fitness benefits of functional electrical stimulation-evoked leg exercise for spinal cord-injured individuals. Topics in Spinal Cord Injury Rehabilitation 14(4): 88-121.
Hasnan, N., Ektas, N., Tanhoffer, A.I.P., Tanhoffer, R., Fornusek, C., Middleton, J.W., Husain, R. \& Davis, G.M. 2013. Exercise responses during functional electrical stimulation cycling in individuals with spinal cord injury. Medicine and Science in Sports and Exercise 45(6): 1131-1138.

Hicks, A.L., Ginis, K.A.M., Pelletier, C.A., Ditor, D.S., Foulon, B. \& Wolfe, D.L. 2011. The effects of exercise training on physical capacity, strength, body composition and functional performance among adults with spinal cord injury: A systematic review. Spinal Cord. 49(11): 1103-1127.

Johnston, T.E., Schmidt-Read, M., Marino, R., Oleson, C., Leiby, B. \& Modlesky, C. 2015. Musculoskeletal effects of two functional electrical stimulation cycling paradigms for people with spinal cord injury. Archives of Physical Medicine and Rehabilitation 97(9): 1413-1422.

Kuhn, D., Leichtfried, V. \& Schobersberger, W. 2014. Four weeks of functional electrical stimulated cycling after spinal cord injury: A clinical cohort study. International Journal of Rehabilitation Research 37(3): 243-250.

Liu, C., Chen, S., Chen, C., Chen, T. \& Chen, J.J. 2007. Effects of functional electrical stimulation on peak torque and body composition in patient with spinal cord injury. The Kaohsiung Journal of Medical Sciences 23(5): 232-240.

LiVecchi, M.A. 2011. Spinal cord injury. Continuum: Lifelong Learning Neurology 17(3): 568-583.

Lynch, C.L., Popovic, M.R. \& Rushton, D. 2008. Functional electrical stimulation. IEEE Control Systems Magazine 28(2): 40-50.

National Spinal Cord Injury Database. 2015. www.nscisc.uab edu/nscisc-database.aspx.

Peckham, P.H. \& Knutson, J.S. 2005. Functional electrical stimulation for neuromuscular applications. Annual Review of Biomedical Engineering 7(1): 327-360.

Ragnarsson, K.T. 2008. Functional electrical stimulation after spinal cord injury: Current use, therapeutic effects and future directions. Spinal Cord 46(4): 255-274.

Sadowsky, C.L., Hammond, E.R., Strohl, A.B., Commean, K., Eby, S.A., Damiano, D.L., Wingert, J.R., Bae, K.T. \& McDonald, J.W. 2013. Lower extremity functional electrical stimulation cycling promotes physical and functional recovery in chronic spinal cord injury. J. Spinal Cord. Med. 36(6): 623-631.

Sköld, C., Lönn, L., Harms-Ringdahl, K., Hultling, C., Levi, R., Nash, M. \& Seiger, Å. 2002. Effects of functional electrical stimulation training for six months on body composition and spasticity in motor complete tetraplegic spinal cord-injured individuals. Journal of Rehabilitation Medicine 34(1): 25-32.

Thrasher, T.A., Ward, J.S. \& Fisher, S. 2013. Strength and endurance adaptations to functional electrical stimulation leg cycle ergometry in spinal cord injury. NeuroRehabilitation 33(1): 133-138.

Thrasher, T.A., Flett, H.M. \& Popovic, M.R. 2006. Gait training regimen for incomplete spinal cord injury using functional electrical stimulation. Spinal Cord 44(6): 357-361.

Westcott, W.L. \& Rosa, S.A. 2010. Spinal cord injury. Strength and Conditioning Journal 32(6): 16-18.

Nurhaida Rosley \& Haidzir Manaf*

Centre of Physiotherapy

Faculty of Health Sciences

Universiti Teknologi MARA (Puncak Alam Campus) 
42300 Puncak Alam, Selangor Darul Ehsan Malaysia

\section{Nur Azah Hamzaid}

Department of Biomedical Engineering Faculty of Engineering, University Malaya 50603 Kuala Lumpur, Federal Territory Malaysia

Nazirah Hasnan

Department of Rehabilitation Medicine Faculty of Medicine, University Malaya 50603 Kuala Lumpur, Federal Territory Malaysia
Glen M Davis

Department of Clinical Exercise and Rehabilitation Unit Faculty of Health Science, University of Sydney Camperdown NSW 2006

Australia

*Corresponding author; email: haidzir5894@uitm.edu.my

Received: 19 July 2017

Accepted: 9 January 2019 